\title{
Spreading Agglutinated Foraminifera near Rift Structures of West-Siberian and Other Provinces
}

\author{
V. M. Podobina \\ Tomsk State University, Tomsk, Russia \\ Email: podobina@ggf.tsu.ru
}

How to cite this paper: Podobina, V.M. (2017) Spreading Agglutinated Foraminifera near Rift Structures of West-Siberian and Other Provinces. Open Journal of Geology, 7, 1739-1748.

https://doi.org/10.4236/ojg.2017.711116

Received: August 21, 2017

Accepted: November 27, 2017

Published: November 30, 2017

Copyright $\odot 2017$ by author and Scientific Research Publishing Inc. This work is licensed under the Creative Commons Attribution International License (CC BY 4.0).

http://creativecommons.org/licenses/by/4.0/

\section{(c) (i) Open Access}

\begin{abstract}
Agglutinated quartz-siliceous foraminifera are widely spread in West Siberian, at least in Canadian and Middle Asia provinces. Considerable amounts of these forms are assigned to the rift structures which stretch out in the meridional direction in these provinces. The foraminifera assemblages of these forms may have been formed in the Arctic basin. As an example, we have studied agglutinated foraminifera of the Cenomanian-Turonian in the provinces along the rift to which industrial hydrocarbon field is assigned. The Plates 1-4-Cenomanian-Turonian agglutinated foraminifera of West-Siberian provinces are presented. Correlation of Foraminiferal zones and layers of West Siberian and Canadian provinces, showing the agglutinated index-species foraminifera are presented.
\end{abstract}

\section{Keywords}

Rift, Agglutinated Foraminifera, Cenomanian-Turonian, Western Siberia

\section{Introduction}

Agglutinated quartz-siliceous foraminifera were discovered in the Cretaceous and Paleogenic deposits of Western Siberia. In large amounts, they are assigned to the meridionally extended rift and its ramifications. The Koltogorsko-Urengoisky megasag is located in the West-Siberian relief, just above and hear the rift agglutinated foraminiferal taxa are supposed to have come into being in the Arctic basin and further they stretched out in the southern direction to the corresponding ecological niches in the areas of the West-Siberian, at least in Canadian and Middle Asia provinces. But in Western Siberia, however, their connection with the southern provinces was limited because the Turgay strait was shallow in 
the course of time or it was completely blocked and because of the ecological barriers for the migration of the secreted calcareous foraminiferal forms from the south. Therefore, during the Cretaceous and the Paleogene agglutinated quartz-siliceous foraminifera were abundant in large amounts in the West-Siberian province especially near rift and its ramifications. In contrast to the WestSiberian in Canadian province, a direct connection with the Southern Seas was fulfilled by means of the Western inner strait or "Sea Way". Owing to it in the Canadian province with agglutinated quartz-siliceous foraminifera secretedcalcareous forms make up a considerable proportion. In Western Siberia the Cenomanian, Turonian, Santonian as well as the Paleocene-Eocene assemblages of agglutinated foraminifera are widely spread almost without calcareous forms. These agglutinated foraminifera reached upon considerable amount near the meridionally located rift and its ramifications. The Apt-Albian agglutinated foraminiferal assemblages are discovered in the West-Siberian province near this structure mainly in the northern palaebiogeographical district (to the north from the latitudinal stream of the river $\mathrm{Ob}$ ).

Transuralia represented the strait with the predominant Arctic influence during the Albian-upper Cretaceous and Paleogene. It was very far from rift structure, because agglutinated and isolated secreted calcareous forms were spread [1].

Assignment of agglutinated quartz-siliceous foraminifera to the rift structures of Northern America (Western Canada) and Middle Asia is observed with the exception of Western Siberia. In these provinces one can consider the meridional location and the connection of this rift with the West-Siberian rift. Evidently, during the activization of the rift, a great amount of silicic acid which was necessary to form shells of agglutinated quartz-siliceous foraminifera came to the basin for the sedimentation.

We observe the genera and species of just the same type at these stratigraphical levels in the provinces which are compared. During the Cretaceous and the Paleogene the Western inner basin or "Sea Way" of Northern America was probably located above the similar rift. This is proved by the author on the basis of the foraminiferal researches. The extension of this rift is possible within the boundaries of the Arctic. As it was pointed out, further in the middle part of Western Siberia and here just above the Koltogorsko-Urengoisky megasag is observed. In Middle Asia, the rift extends in the southern and meridional direction. The finds of the similar agglutinated quartz-siliceous foraminifera in the established provinces are usually assigned to the areas of industrial oil and gas fields supplied with hydrocarbons along the indicated rift and their ramifications. In Table 1, you can see the correlation of Cenomanian-Turonian micropaleontological zones of agglutinated foraminifera of West Siberian and Canadian provinces in Arctic realm. Names of all index-species of micropaleontological zones are agglutinated foraminifera.

The investigations are very important because shown where concentrations of the industrial hydrocarbons may be. 


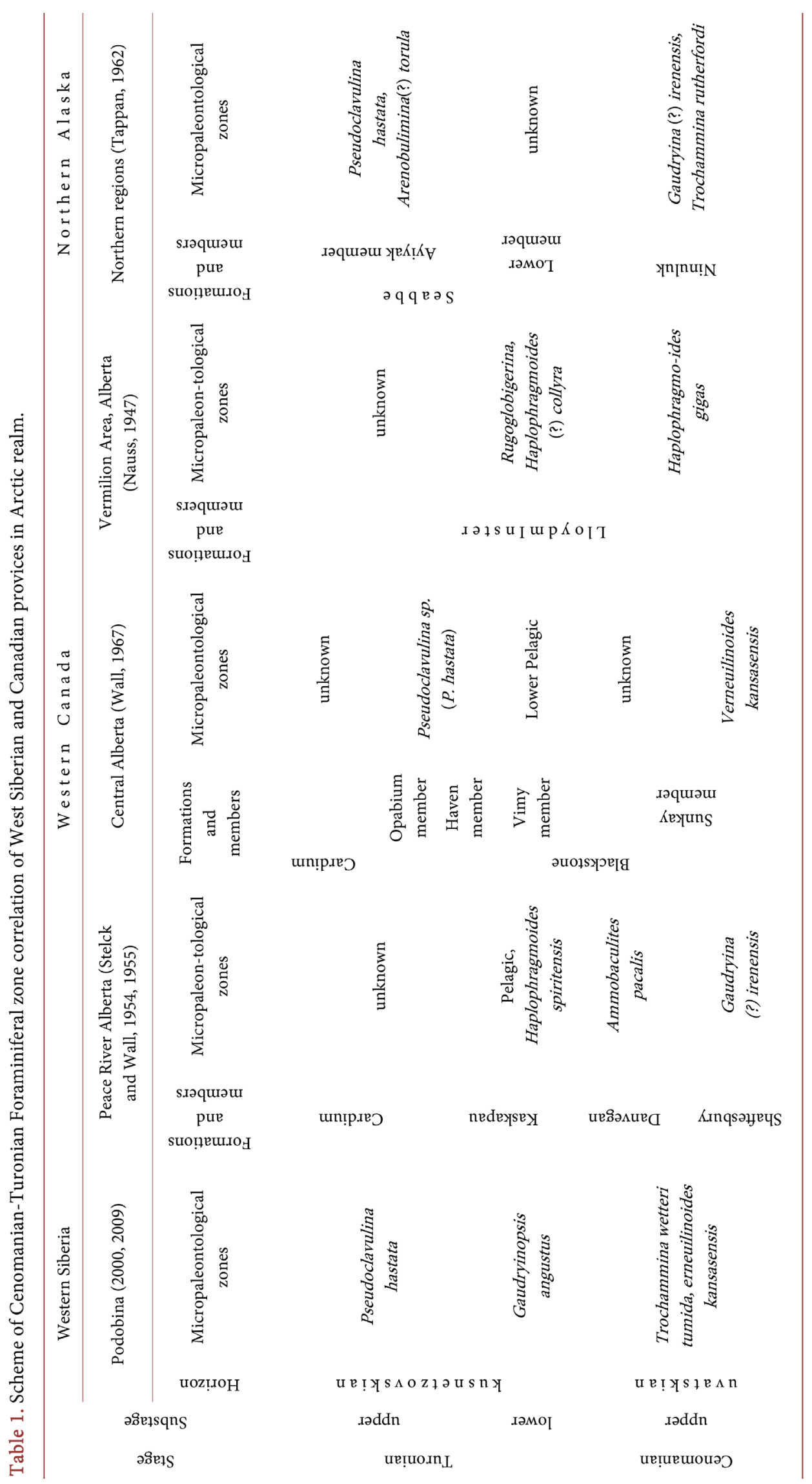




\section{The Methods and Material of Studying}

Foraminifera on which nave based all investigations are studied by Micropaleontological, Paleogeographical and Paleobiogeographical methods. The first metod have given us many foraminiferal specimens especially their agglutinated shells. These shells have been studied under MIN 8, MIN 10 and electronic Microscops. Under Microscops have been studied morphology and content of the wall of agglutinated foraminifera, consisting from kwarts-siliceus material [2].

Palogeographical methods have used for the marks of the marine and continental facies spreading during Cenoman-Turonian [3]. The Cenomanian marine bacies with agglutinated foraminifera have spread only in Northern part on the territory of Western Siberia (from latitudinal stream of the Ob River, including Yamal Peninsula). The remain territory consist of Cenomanian continental bacies. The Turonian marine facies spread on the all territory of Western Siberia and include especially agglutinated kwartz-siliceus foraminifera.

The third Method-Paleobiogeographical have been used for the division of the West Siberian province on the several districts, having the different foraminiferal assemblages [3] [4]. The Cenomanian agglutinated foraminifera have been finded only in Northern district. The Turonian agglutinated foraminifera spread in Central and Northern districts. In this paper author have studied material the Cenomanian agglutinated foraminifera from Northern district and Turonian one from Central and Northern districts.

The foraminiferal assemblages obtained as the result of the microfaunistic analysis of 114 kern samples of the seven borehole sections (1002, 2010, 2031, $169,3618,2050,163$ of the Van-Eganskaya area (the Northern palaebiogeographical district northwards of the latitudinal stream of the river $\mathrm{Ob}$ ) have been investigated in detail. This area is near meridional rift. The deposits of the upper Cenomanian and Turonian are established in the sections of these boreholes according to the systematic composition of the studied assemblages [9] [10] (Plates 1-4).

\section{Results of the Investigation}

West Siberian Cenomanian-Turonian deposits include industrial hydrocarbons (the Cenomanian) as well as a good cover (the Turonian). Big gas fieds of the Uvatskian Horizon (Cenomanian) mainly assigned to the area of Koltogorsko-Urengoisky megasag are of great importance. We investigated the foraminiferal assemblages of a number of boreholes of the Parusovaya, Tazovskaya, Purpeiskaya, Southern Russkaya, Van-Eganskaya and the other areas of the northern district of Western Siberia where the biggest gas fields were discovered in Cenomanian deposits. The sections of the boreholes southwards of the latitudinal stream of the River $\mathrm{Ob}$ also worth mentioning because they include similar assemblages of mainly agglutinated foraminifera: isolated in the Cenomanian (the Uvatskian Horizon) and abundant in the Turonian (the Kuznetsovskian Horizon) [5]-[11] (Figure 1). 


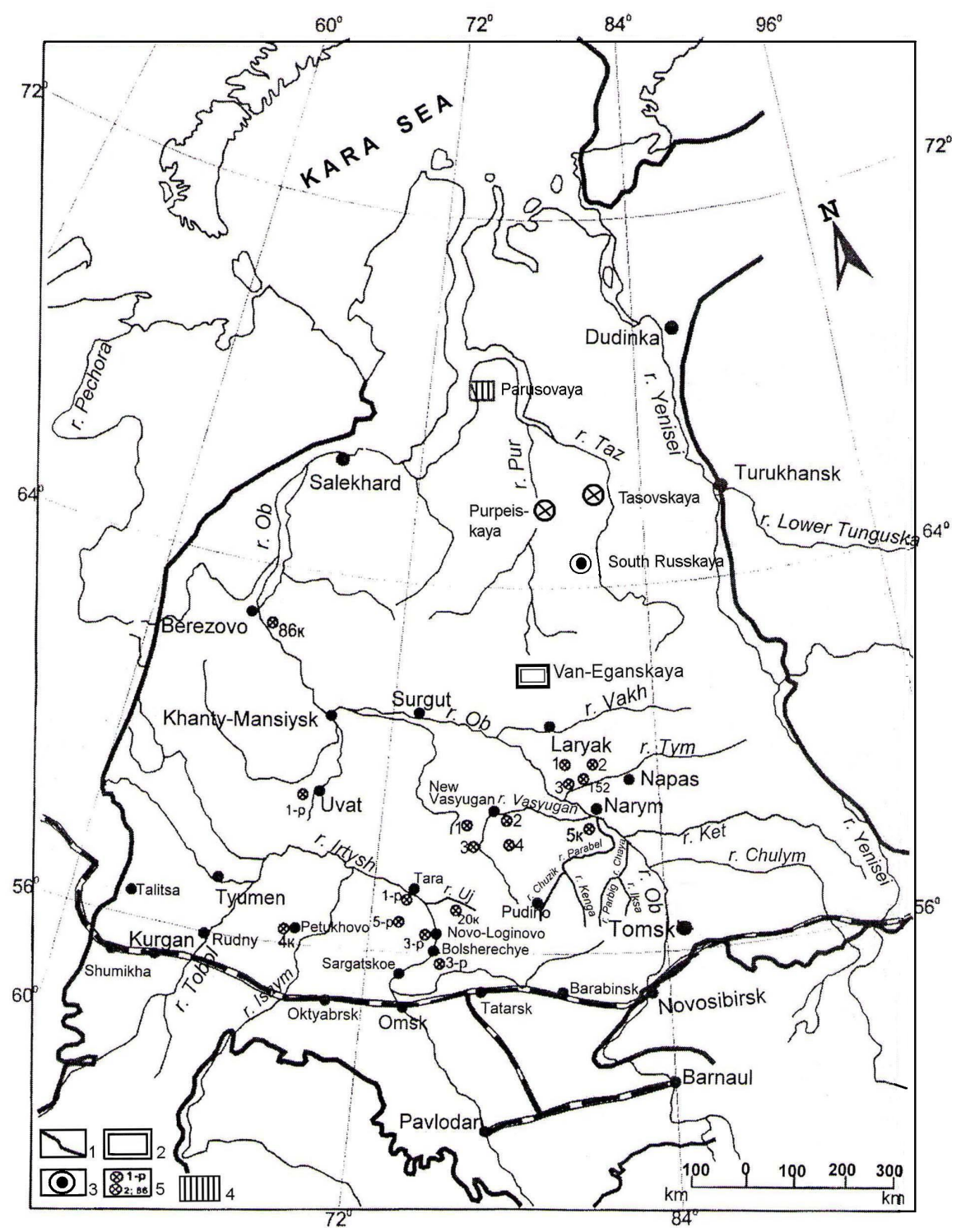

Figure 1. Map of situation of research area and boreholes. 1) boundary of West-Siberian plain; 2) Van-Eganskaya area; 3) South Russkaya area; 4) Parusovaya area; 5) boreholes of various depths.

Two zones: (the lower)-Saccammina micra, Ammomarginulina sibirica and (the upper)-Trochammina wetteri tumida, Verneuilinoides kansasensis are established with regard to agglutinated foraminifera in the upper Cenomanian according to the foraminiferal assemblages composition and the lithology of content rocks in the investigated seven borehole sections (Van-Eganskaya area). In the lower part of the upper zone the layers with Gaudryinopsis nanushukensis elongatus are traced. Significal facies differences (alternation of shallow water and continental facies) are observed along the section of all the Uvatskian Horizon but in some sections of its upper layers marine facies of dark-grey clays prevail and well-preserved foraminiferal assemblages of the upper Cenomanian zone are assigned to them. 


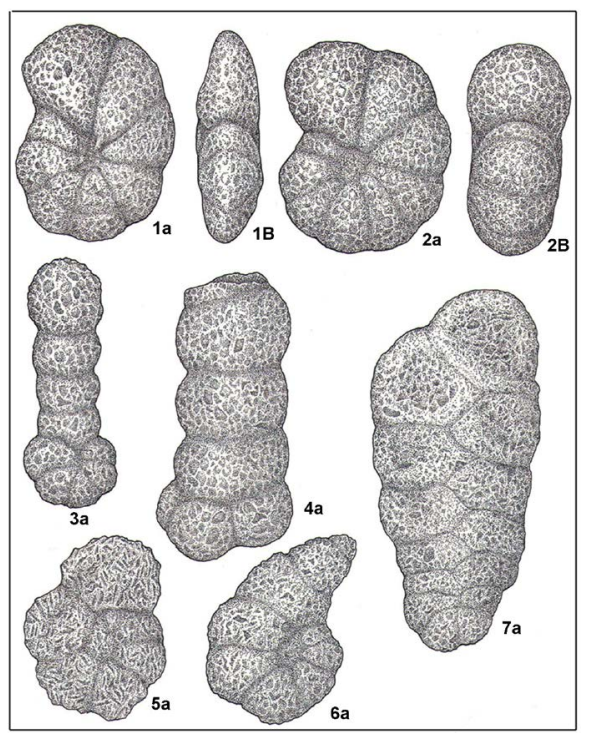

Plate 1. Western Siberia, Van-Eganskaya area, borehole 2031, depth $945.0 \mathrm{~m}$; Uvatskian Horizon, upper Cenomanian; a) Lateral or dorsal view; b) Apertural view; 56×. 1) Haplophragmoides variabilis Podobina. Golotype No. 3203. 2) Labrospira rotunda Podobina. Golotype No. 3203. 3) Ammobaculites wenonahae Tappan. Specimen No. 3205. 4) Haplophragmium ivlevi Podobina. Golotype No. 3209. 5) Ammoscalaria senomanica Podobina. Golotype No. 3208. 6) Ammomarginulina sibirica Podobina. Golotype No. 3206. 7) Spiroplectammina longula Podobina. Golotype No. 3213.

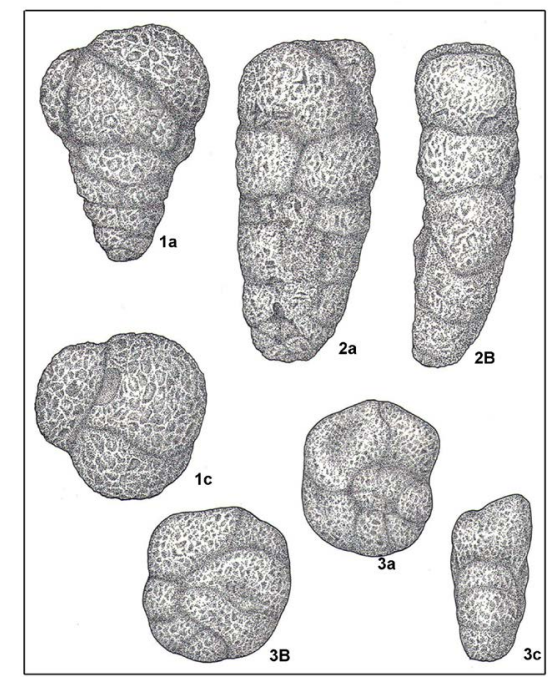

Plate 2. Western Siberia, Van-Eganskaya area, borehole 2031, depth 945,0 m; Uvatskian Horizon, upper Cenomanian; a) Lateral or dorsal view; $b$ ) Lateral or ventral view; $c$ ) Apertural view, 56×. 1) Verneuilinoides kansasensis Loeblich et Tappan. Specimen No. 3217. 2) Gaudryinopsis nanushukensis Tappan subsp. elongatus Podobina. Golotype subspecies No. 3212. 3) Trochammina subbotinae Zaspelova subsp. mutabila Podobina. Golotype subspecies No. 3220. 


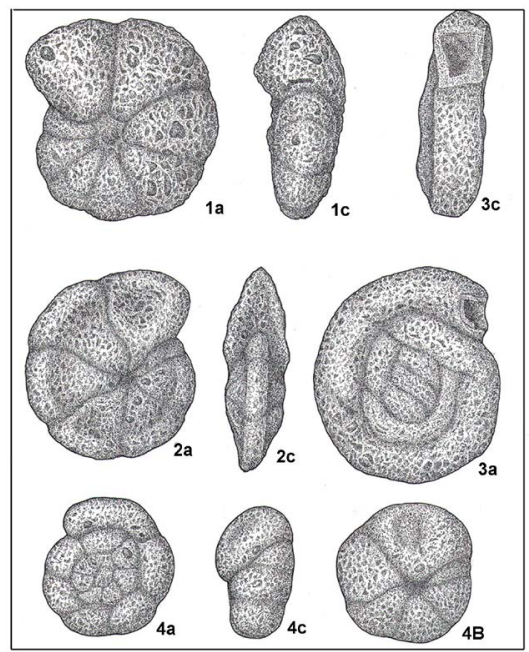

Plate 3. Western Siberia, Van-Eganskaya area, borehole 2031, depth 930,35 m; Kuznetsovskian Horizon, lower Turonian; a) Lateral or dorsal view; b) Ventral view; $c$ ) Apertural view, 56×. 1) Labrospira collyra (Nauss). Specimen № 3261a. 2) Haplophragmoides rota Nauss subsp. sibiricus Zaspelova. Specimen No. 3263. 3) Lituotuba confusa (Zaspelova). Specimen No. 3254. 4. Trochammina arguta Podobina. Specimen No. 3255.

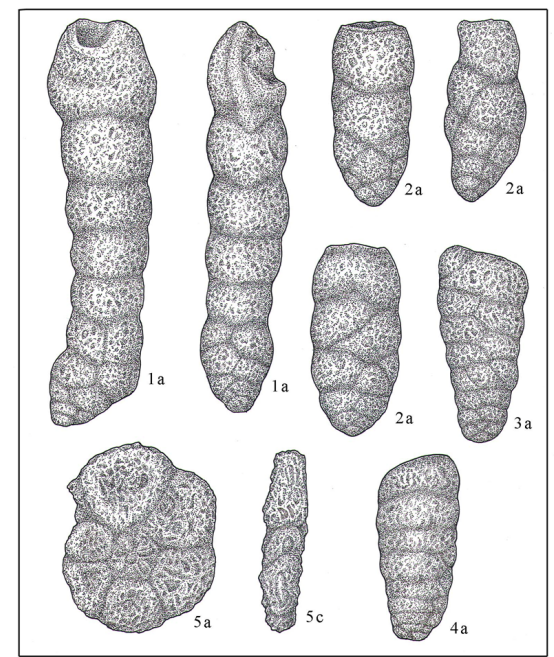

Plate 4. Western Siberia, Van-Eganskaya area, borehole 2031, depth 930.35 m; Kuznetsovskian Horizon, lower Turonian; a) Lateral view; c) Apertural view, 56×. 1-2. Pseudoclavulina hastata (Cushman): 1) Specimen No. 3250, 2) Specimen No. 3251. 3-4. Gaudryinopsis angustus Podobina: 3) specimen No. 3252, 4) Specimen No. 3253. 5) Ammoscalaria antis Podobina. Specimen No. 3265.

Similar well-preserved assemblages at this stratigraphic level were earlier noticed in dark-grey, almost black clays of the upper parts of the Uvatskian Horizon in the borehole sections of the Tazovskaya and Purpeiskaya areas [10] [11]. 
The study of clayey covers which have preserved hydrocarbon deposits from destruction is of no less significance. They include dark-grey clays of the above lying Kuznetsovskaya suite (the Turonian) of just the name Horizon which are almost widely spread within Western Siberia. Earlier, in the Kuznetsovskaya suite (the same name of Horizon) two agglutinated foraminiferal assemblages: (the lower) with Gaudryinopsis angustus and (the upper) with Pseudoclavulina hastata had been determined [8] [10]. The rocks of the lower and the upper layers of the Kuznetsovskaya suite characterized by these assemblages represent just the same zones corresponding to the lower and upper Turonian. Just the same zones are traced into two sections (boreholes 1002, 2031) of the Kuznetsovskaya suite of the Van-Eganskaya area to be compared. It should be noted that in the section of borehole 1002 in the lower part of Gaudryinopsis angustus zone the layers with Hedbergella loetterlei having prevailing forms of the Hedbergella genus are established [10].

A correlation of the late Cenomanian-Turonian assemblages, mainly agglutinated foraminifera of West-Siberian and Canadian provinces within the entire Arctic palaebiogeographical realm is made. In the comparison of these assemblages made in the West-Siberian province common species, geographical subspecies and vicarious (substituting) species of the Canadian taxa are established. Owing to such comparison, a detailed correlation and clarification of the age of the foraminiferal zones, layers and the stratigraphic position of the West-Siberian stratons of the upper Cenomanian-Turonian with regard to the stratons of the Canadian province concerned are made [8] [9] [10] [14]-[19] (Table 1).

The correlation of the West-Siberian Cenomanian assemblages with those of Middle Asia shows that the assemblages being compared are different in their systematic composition and only in some places similar or vicarious species are traced. In the lower reaches of the Amu-Darja and Kyzylkum [12] Cenomanian deposits in view of foraminiferal assemblages content are subdivided into two zones. Among them, agglutinated foraminifera prevail and Trochammina kugitangensis $\mathrm{N}$. Bykova, T. cenomanica Zhukova are probably vicarious West-Siberian Trochammina wetteri Stelck et Wall tumida Podobina. In the upper layers calcareous shells of the genera-Palmula, Discorbis, Rotaliatina which have not discovered in the West-Siberian deposits of just the same age here are abundant. According to Z.I. Ptushkina [13], the upper Cenomanian deposits of Eastern Turkmenia, just in the area of Gaurdak contain two zones: (the lower)-Rotaliatina and (the upper)-Paragaudryina (?) asiatica. The foraminiferal assemblages of the upper zone including agglutinated shells of the genera Haplophragmoididae and Ataxophragmiidae are similar to the Western Siberia-Haplophragmoides variabilis, Trochammina wetteri tumida, Verneuilinoides kansasensis of just the same age.

Marine deposits of the West-Siberian lower Turonian formed by grey, dark grey clays, sometimes alevrolits belong to the lower part of the Kuznetsovskaya suite just of the same name Horizon and they are widely spread in the territory being studied [5]-[10]. 
In contrast to the agglutinated foraminifera forms of the Cenomanian assemblages, the content of the representatives of the genera Gaudryinopsis and Haplophragmodes (Gaudryinopsis angustus Podobina and Haplophragmodes rota Nauss sibiricus Zaspelova) increases in the Turonian. The quantity of Trochammina and some Ammobaculites decreases, Uvigerinammina manitobensis (Wickenden) is almost completely absent. Here the species Pseudoclavulina hastata (Cushman) appears and develops which characteristic of their analogous deposits of the Canadian province. The other of the well-known West-Siberian species have existed in the Turonian since the Cenomanian. They are closely related to the foraminiferal forms the Cenomanian-Turonian deposits of Canada (Canadian Province) in view of species respect.

\section{Conclusions}

Hence, West-Siberian and Canadian Cenomanian-Turonian mainly agglutinated foraminifera are similar in their systematic composition not only at a genera but a species level. More than half assemblages to be compared are common, vicarious or they are subspecies of the American species. Middle Asian forms of the same age are less similar although they are located along the rift. Here, characteristic agglutinated foraminifera are isolated but calcareous forms are more significant in their quantity and diversity. The further detailed investigations of West-Siberian and Middle Asian foraminiferal species discovered in the deposits along the rifts will allow us to determine their considerable similarity. The occurrence of agglutinated foraminifera within and near rift structures of the indicated provinces is usually assigned to industrial oil and gas fields.

Plates 1-4 show the characteristic taxa (genera and species of agglutinated foraminifera) of the Upper Cenomanian and Lower Turonian of Western Siberia (Van-Eganskaya Area, borehole 2031).

\section{References}

[1] Bulatova, Z.I. (1976) Stratigraphy Apt-Albian Oil-Gas Bearing Deposits of the West Siberian Province on Foraminifera. Nedra, 125 p. [In Russian]

[2] Podobina, V.M. (1978) Sistematic and Philogeny of Haplophragmiidea. University Press, Tomsk, 91 p. [In Russian]

[3] Podobina, V.M. (2000) Foraminifera and Biostratigraphy of the Upper Cretaceous in Western Siberia. Scientific Technical Literature Press, Tomsk, 338 p. [In Russian]

[4] Podobina, V.M. (1995) Paleozoogeographic Regionalization of Northern Hemisphere Late Basin Based on Foraminifera. Proceedings of the 4th International Workshop on Agglutinated Foraminifera, Spec. Publ., 239-247.

[5] Podobina, V.M. (1975) Foraminifera of the Upper Cretaceous and Palaegene of the West-Siberian Lowland, Their Significance for the Stratigraphy. Tomsk University Press, Tomsk, 163 p. [In Russian]

[6] Podobina, V.M. (1989) Foraminifera and Zonal Stratigraphy of the Upper Cretaceous of Western Siberia. Tomsk University Press, Tomsk, 175 p. [In Russian]

[7] Podobina, V.M. (1998) Foraminifera and Biostratigraphy of the Paleogene of Western Siberia. Scientific Technical Literature Press, Tomsk, 338 p. [In Russian] 
[8] Podobina, V.M. (2009) Foraminifera, Biostratigraphy of the Upper Cretaceous and Palaegene in Western Siberia. Tomsk University Press, Tomsk, 430 p. [In Russian]

[9] Podobina, V.M. (2012) New Data on Foraminifera and Biostratigraphy of the Upper Cenomanian of the West-Siberian Northern Area. Tomsk State University Bulletin, 361, 182-187. [In Russian]

[10] Podobina, V.M. (2012) New Data on Turonian Biostratigraphy and Foraminifera of Western Siberia. Tomsk State University Bulletin, 364, 181-184. [In Russian]

[11] Podobina, V.M. and Tanacheva, M.I. (1967) Stratigraphy of Gas-Bearing of the Upper Cretaceous of the Deposits of North-Eastern Area of the West-Siberian Lowland. New Data on the Geology and Economic Minerals of Western Siberia: Issue 2. Tomsk, Tomsk University Press, 89-99. (In Russian)

[12] Zhukowa, E.A. (1959) Some New Data on the Senomanian and Turonian Layers in the Lower Parts of Amu-Darja and Kyzyl-Kum on the Foraminiferal Fauna. Report of the Academy of Sciences of the Uzbek Soviet Republic, No. 1, 15-16. (In Russian)

[13] Ptushkina, Z.I. (1975) Agglutinated Foraminifera of Eastern Turkmenia Deposits: Synopsis of a Candidate of Geological and Mineralogical Sciences. L., 23 p. (In Russian)

[14] Tappan, H. (1962) Foraminifera form the Arctic Slope of Alaska. Pt. 3, Cretaceous Foraminifera. U.S. Geol. Survey Prof. Paper. No. 236G, 91-209, 30 pls.

[15] Wall, J. (1967) Cretaceous Foraminifera of the Rocky Mountain Foothills, Alberta. Research Council of Alberta, Bulletin 20, 185 p, 15 pls.

[16] Wall, J. (1983) Jurassic and Cretaceous Foraminiferal Biostratigraphy in the Eastern Sverdrup Basis, Canadian Arctic Archipelago. Canadian Petroleum Geology Bulletin, 31, 246-281, 7 pls.

[17] Nauss, A.W. (1947) Cretaceous Microfossils of the Vermilion Area Alberta. Journal of Paleontology, 21, 329-343, pls. 48-49.

[18] Stelck, C. and Wall, J. (1954) Kaskapau Foraminifera from Peace River Area of Western Canada. Research Council of Alberta, Report 68, 6-38, 3 pls.

[19] Stelck, C. and Wall, J. (1955) Foraminifera of the Cenomanian Dunveganoceras Zone from Peace River Area of Western Canada. Research Council of Alberta, Report 70, 6, 4 pls. 